\title{
Kompetensi Pedagogik Guru Pendidikan Agama Islam Dalam Mengelola Proses Pembelajaran di SD Negeri Bulupitu Kecamatan Gondanglegi Kabupaten Malang
}

\author{
Mudhofar \\ Institut Agama Islam Al-Qolam Gondanglegi Malang \\ kholifahmudhofar@gmail.com
}

\begin{abstract}
ABSTRAK
Kebutuhan Pedagogik bagi Guru adalah diantaranya Guru bisa memahami karakter siswanya, guru memahami latar belakang siswanya baik dari segi kondisi ekonomi orang tuanya maupun lingkungan, guru bisa memahami dan mampu mendesain dan merencanakan pembelajaran, guru mampu dan mengusai mengajar dengan bermacam-macam model dan metode pembelajaran sehingga cara mengajar tidak monoton, guru mampu sebagai motivator, insprirator dan menjadi guru yang kreatif dan inovatif. Disebut guru yang professional adalah guru yang mempunyai empat komptensi, salah satunya adalah kompetensi pedagogik sehingga kompetensi pedagogik penting dalam penerimaan guru baru.

Focus penelitian dalam kompetensi pedagogik ini ditekankan pada: 1) bagaimana kompetensi pedagogic 2) faktor pendukung dan penghambat guru dalam mengelola proses pembelajaran dan 3) bagaimana upaya guru tersebut. Dengan menggunakan metode kualitatif kompetensi pedagogik bertujuan untuk mengetahui Kompetensi Pedagogig Guru Pendidikan Agama Islam Serta faktor pendukung dan penghambat, juga mendeskripsikan upaya guru dalam mengatasi suatu hambatan. Berdasarkan data dari hasil wawancara, observasi, dan studi dokumentasi dapat disimpulkan oleh peneliti bahwa kompetensi pedagogik guru PAI sudah terlaksana dengan baik.
\end{abstract}

Kata Kunci : Kompetensi pedagogik, Mengelola Proses Pembelajaran

\section{PENDAHULUAN}

Seiring dengan kemajuan ilmu pengetahuan dan teknologi yang semakin canggih, manusia dituntut untuk terus belajar dan terus menambah ilmu pengetahuan serta pengalaman, agar tidak asing lagi terhadap perubahan zaman yang semakin maju. Oleh karena itu, kemajuan ilmu pengetahuan dan teknologi harus diikuti sesuai dengan perubahan zaman yang semakin maju ini, pendidikan merupakan masalah fundamental dalam pembangunan bangsa yang erat hubungannya dengan usaha mencerdaskan kehidupan bangsa.

"Salah satu wujud nyata dalam usaha mencerdaskan kehidupan bangsa itu adalah melalui kegiatan pembelajaran, dengan cara ini anak diharapkan dapat menyerap pengetahuan sebanyak-banyaknya dan sekaligus dapat menerapkan dalam kehidupan bermasyarakat dan berbangsa."1

Pendidik (guru) dalam proses belajar mengajar memiliki peran kunci dalam menentukan kualitas pembelajaran. Guru diharapkan dapat menunjukkan kepada siswa tentang bagaimana cara mendapatkan pengetahuan (cognitive), sikap dan nilai (affektif) dan keterampilan (psikomotor). Dengan kata lain tugas dan peran pendidik yang utama adalah terletak aspek pembelajaran. Pembelajaran merupakan alat untuk mencapai tujuan pendidikan. Oleh karena itu secara singkat dapat dikatakan bahwa, kualitas pendidikan sangat dipengaruhi oleh kualitas pendidiknya.

${ }^{1}$ Suparlan. Menjadi Guru Efektif. (Yogyakarta: Hikayat. 2003) halaman 99. 
Dalam UU Sisdiknas Nomor 20 tahun 2003 pasal 29 ayat 2 menyebutkan bahwa: "Pendidik merupakan tenaga profesional yang bertugas merencanakan dan melaksanakan proses pembelajaran, menilai hasil pembelajaran, melakukan pembimbingan dan pelatihan. Dalam konteks sistem pendidikan nasional tersebut, seorang pendidik harus memiliki kemampuan untuk mewujudkan tujuan pendidikan nasional."2

Sebagaimana Peraturan Pemerintah Republik Indonesia nomor 19 Tahun 2005 tentang Standar Nasional Pendidikan, pasal 28 ayat 3, menyatakan bahwa: "Ada empat kompetensi yang harus dimiliki guru sebagai figur sentral proses pendidikan dan peningkatan kecerdasan sebuah bangsa. Keempat kompetensi itu adalah: kompetensi pedagogik, kompetensi profesional (akademik), kompetensi kepribadian dan kompetensi sosial."3

Agar peran dan tugas guru dapat terwujud dengan sebaik-baiknya, maka hal yang inti adalah terletak pada kompetensi guru. Guru sebagai tenaga pengajar dan pendidik adalah figur sentral dalam kegiatan pembelajaran dan berlangsung tidaknya atau berhasil tidaknya kegiatan pembelajaran ditentukan oleh seorang guru. Sehingga mutu pendidikan amat ditentukan oleh mutu gurunya. ${ }^{4}$

Pada penelitian ini peneliti akan fokus meneliti mengenai kompetensi pedagogik guru Pendidikan Agama Islam (PAI) dalam mengelola proses pembelajaran di SD Negeri Bulupitu Kecamatan Gondanglegi Kabupaten Malang. Penelitian ini diharapkan menjadikan masukan bagi siswa, guru dan pengambil kebijakan pada umumnya untuk perbaikan dimasa yang akan datang.

\section{METODE PENELITIAN}

Metode yang digunakan untuk mengkaji mengenai kompetensi pedagogik guru pendidikan agama islam (PAI) dalam mengelola proses pembelajaran di SD Negeri Desa Bulupitu Kecamatan Gondanglegi Kabupaten Malang adalah metode kualitatif. Metode penelitian kualitatif sering disebut metode penelitian naturalistik karena penelitiannya dilakukan pada kondisi yang alamiah (natural setting). Penelitian dilakukan pada obyek yang alamiah. Obyek yang alamiah adalah obyek yang berkembang apa adanya, tidak dimanipulasi oleh peneliti dan kehadiran peneliti tidak mempengaruhi dinamika pada obyek tersebut. ${ }^{5}$ Sementara untuk jenis penelitian menggunakan penelitian deskriptif.

"Penelitian deskriptif tidak dimaksudkan untuk menguji hipotesis tertentu, tetapi hanya menggambarkan ,apa adanya,, tentang suatu variabel gejala atau keadaan."6 Penelitian ini bertujuan untuk memberikan gambaran tentang suatu gejala/suatu masyarakat tertentu."7 Jika dilihat dari lokasi penelitiannya, maka jenis penelitian ini merupakan jenis penelitian lapangan (field research).

${ }^{2}$ Ahmad Fatah Yasin. Pengembangan Kompetensi Pedagogik Guru Pendidikan Agama Islam di Madrasah (Studi Kasus di MIN Malang I). Jurnal El-Qudwah. April 2012. Vol. 1, No. 5, pp. 157-181. http://ejournal.uinmalang.ac.id/index.php/lemlit/article/view/ 1942 (diakses pada 9 September 2018).

${ }^{3}$ Hamka Abdul Aziz. Karakter Guru Profesional. (Jakarta: Al-mawardi Prima. 2012) halaman 231.

${ }^{4}$ Suparlan. Menjadi Guru Efektif. (Yogyakarta: Hikayat. 2003) halaman 99.

${ }^{5}$ Sugiyono. Metode Penelitian Kuantitaif, Kualitatif dan R\&D. (Bandung: Alfabeta. 2017) halaman 8.

${ }^{6}$ Suharsimi Arikunto. Manajemen Penelitian. (Jakarta: PT Rineka Cipta. 2005) halaman 234.

${ }^{7}$ Sukandarrumidi. Metodologi Penelitian. (Yogyakarta: Gadjah Mada Unversity Press. 2006) halaman 104. 
"Penelitian lapangan adalah untuk mempelajari secara intensif tenta latar belakang keadaan sekarang, dan interaksi lingkungan suatu unit sosial: individu, kelompok, lembaga, atau masyarakat."8

Dijelaskan juga dalam bukunya Nana Sayodih Sukmadinata metode kualitatif yakni "suatu penelitian yang ditunjukkan untuk mendeskripsikan dan menganalisis fenomena atau peristiwa. Dengan pendekatan penelitian deskriptif yaitu penelitian yang ditunjukkan untuk menggambarkan fenomea-fenomena yang ada yang berlangsung saat ini atau saat yang lampau. ${ }^{9}$ Alasan memilih pendekatan penilitian ini karena bertujuan untuk mendeskripsikan dan menggambarkan secara sistematis, aktual dan akurat mengenai permasalahan dalam penelitian ini.

Bodgan dan Taylor mendefinisikan metodologi kualitatif sebagai prosedur penelitian yang menghasilkan data deskriptif berupa kata-kata tertulis atau lisan dari orang-orang dan perilaku seseorang yang dapat diamati. ${ }^{10}$ Alasan memilih pendekatan penilitian ini karena bertujuan untuk mendeskripsikan dan menggambarkan secara sistematis, aktual dan akurat mengenai permasalahan dalam penelitian ini.

\section{Sumber Data}

Sumber data dimaksudkan semua informasi baik yang merupakan benda nyata, sesuatu yang abstrak, peristiwa/gejala baik secara kuantitatif ataupun kualitatif. Sumber data yang bersifat kualitatif didalam penelitian diusahakan tidak bersifat subjektif, oleh sebab itu perlu diberi peringkat bobot.

Sumber data adalah dari mana data dapat diperoleh sedangkan menurut Lofland menyatakan bahwa sumber data utama dalam penelitian kualitatif adalah kata-kata dan tindakan, dan selebihnya adalah data tambahan seperti dokumen dan lain-lain. ${ }^{11}$

"Sumber data kualitatif adalah sumber data yang disuguhkan dalam bentuk dua parameter ,abstrak,, misalnya: banyak-sedikit, tinggi-rendah, tua-muda, panas-dingin, situasi aman-tidak aman, laba-nirlaba."12 Sugiyono juga menjelaskan bahwa:

"Pengambilan sumber data dalam melakukan penelitian kualitatif dipilih secara purposive dan snowball sampling. Sampel sumber data padatahap awal memasuki lapangan dipilih orang yang memiliki power atau otoritas pada situasi sosial atau obyek yang diteliti, sehingga mampu ,membukakan pintu,, kemana saja peneliti akan melakukan pengumpulan data." 13

Dilihat dari sumber data yang digunakan dalam penyusunan penelitian ini adalah:

1. Data primer yaitu data yang diperoleh secara langsung dari informan dilapangan yaitu melalui wawancara mendalam (indept interview) dan observasi partisipasi dengan guru mata pelajaran Pendidikan Agama Islam.

${ }^{8}$ Sumardi Suryabrata. Metodologi Penelitian.( Jakarta: PT. Raja Grafindo Persada. 2005) halaman 80

${ }^{9}$ Nana Sayodih Sukmadinata. Metode Penelitian Pendidikan. (Bandung: PT Remaja Rosdakarya. 2012) halaman

${ }^{10}$ Lexy J Moleong. Metode Penelitian Kualitatif. (Bandung: PT Remaja Rosdakarya. 2004) halaman 4.

${ }^{11}$ Lexy J Moleong. Metode Penelitian Kualitatif. (Bandung: PT Remaja Rosdakarya. 2004) halaman 157.

${ }^{12}$ Sukandarrumidi. Metodologi Penelitian. (Yogyakarta: Gadjah Mada Unversity Press. 2006) halaman 45.

${ }^{13}$ Sugiyono. Metode Penelitian Kuantitaif, Kualitatif dan R \& D. (Bandung: Alfabeta. 2011) halaman 292-293 
2. Data sekunder yaitu kajian kepustakaan. Metode ini dilakukan untuk mendapatkan data dan teori yang berhubungan dengan kompetensi pedagogik guru pendidikan agama islam (PAI) dalam mengelola proses pembelajaran di SD Negeri Bulupitu Kecamatan Gondanglegi Kabupaten Malang.

\section{HASIL PENELITIAN}

Hasil observasi dan wawancara mendalam dilakukan terhadap kegiatan yang dilakukan oleh guru PAI di SD Negeri Desa Bulupitu Kecamatan Gondanglegi Kabupaten Malang, dapat dideskripsikan hal-hal yang dilakukan oleh guru PAI di SD Negeri Bulupitu dalam mengelola proses pembelajaran. Hasil wawancara dengan Ibu Idatul Magfiroh, S.Pd salah satu guru pendidikan agama islam menjelaskan kompetensi pedagogik guru meliputi:

"Kemampuan dalam memahami peserta didik, kemampuan merancang pembelajaran, kemampuan melaksanakan proses pembelajaran, kemampuan menilai proses dan hasil, dan kemampuan mengembangkan potensi peserta didik". ${ }^{14}$

Pernyataan tersebut dipekuat dengan hasil observasi yang dilakukan peneliti di kelas Ibu Idatul Magfiroh, S.Pd dimana peneliti diperkenankan untuk ikut ke dalam kelas IV dan mengamati proses pembelajaran. Sebelum memasuki ruang kelas Ibu Idatul Magfiroh, S.Pd mempersiapkan bahan ajar (buku pegangan guru), media pembelajaran (laptop dan LCD projector), beserta RPP (Rancangan Pelaksaan Pembelajaran) yang sudah beliau susun sebelumnya. Hasil Observasi tersebut dapat dijabarkan sebagai berikut:

a. Kegiatan Awal

Dari hasil observasi yang peneliti lakukan di kelas Ibu Ibu Idatul Magfiroh, S.Pd. Sebelum memulai pelajaran pendidikan agama islam, Ibu Idatul Magfiroh, S.Pd melakukan absensi terlebih dahulu dan mengkondisikan siswa, dalam metode mengajar Ibu Idatul Magfiroh, S.Pd ini ada yang unik dibanding dengan guru lain pada umumnya, karena sebelum memulai pelajaran siswa ditanya tentang kabar dan kondisi kesehatan mereka dan tidak lupa pula beliau memotivasi siswa dengan cara memberikan perhatian yang lebih kepada siswa yang kurang bersemangat di dalam kelas, kemudian baru memulai proses belajar mengajar dengan mengkonfirmasi materi sebelumnya, Ibu Idatul Magfiroh, S.Pd melakukan tes dengan mengajukan pertanyaan secara lisan kepada siswa, dan siswa yang bisa menjawab selalu diberi reward sebuah permen, walaupun tidak seberapa tapi siswa sangat antusias untuk menjawab soal-soal yang Ibu Idatul Magfiroh, S.Pd berikan. Hal ini dilakukan untuk mengukur sejauh mana pemahaman siswa terhadap materi sebelumnya.

Kegiatan awal pembukaan proses belajar mengajar terlebih dahulu guru mengkondisikan siswa, melakukan apersepsi, konfirmasi terhadap materi-materi yang dibahas pada pertemuan sebelumnya. Serta melakukan tes/kuis yang bisa meningkatkan kemampuan siswa terhadap materi sebelumnya dan materi yang akan dibahas.

\footnotetext{
${ }^{14}$ Wawancara dengan Ibu Idatul Magfiroh, S.Pd. Guru Pendidikan Agama Islam Tanggal 20 Agustus 2018, di Ruang Guru Sekolah Dasar Negeri Bulupitu.
} 
b. Kegiatan Inti Pembelajaran

Proses pembelajaran pendidikan agama islam yang diampu oleh Ibu Idatul Magfiroh, S.Pd di SD Negeri Bulupitu, hal pertama yang menjadi pertimbangan yaitu, pemilihan metode pembelajaran disesuaikan dengan kompetensi atau materi yang harus dikuasai siswa dalam waktu yang tersedia. Pemilihan dan penggunaan strategi atau metode pembelajaran di SD Negeri Bulupitu sudah mengarah pada pemilihan strategi atau metode pembelajaran yang dianjurkan dalam Kurikulum 2013, dapat disimpulkan bahwa metode dan strategi pembelajaran yang digunakan oleh guru PAI di SD Negeri Bulupitu menggunakan metode diskusi kelompok dan lain sebagainya.

Selain itu, dalam proses pembelajaran Ibu Idatul Magfiroh, S.Pd berusaha untuk mengurangi metode ceramah yang monoton, meskipun Ibu Idatul Magfiroh, S.Pd masih menggunakan metode ceramah hanya sekedar untuk mengantarkan siswa dalam memahami materi. Terciptanya proses belajar mengajar yang menyenangkan yaitu ketika Ibu Idatul Magfiroh, S.Pd memberikan kebebasan kepada siswa untuk melakukan sendiri dibawah bimbingan guru, siswa lebih mudah mengingat dan paham materi ketika mereka terlibat langsung dalam proses tersebut.

Hasil observasi atau pengamatan dapat diketahui bahwa selama proses belajar mengajar menggunakan berbagai sumber belajar, antara lain: buku, LKS, buku-buku penunjang lainnya, internet, media masa, dan lain sebagainya. Hal ini juga diungkapkan oleh Ibu Idatul Magfiroh, S.Pd bahwasannya:

Sumber belajar siswa tidak hanya dari buku cetak dan LKS saja, tapi mereka bisa mencari sumber belajar sendiri menggunakan fasilitas yang ada di sekolah seperti mencari informasi dengan menggunakan internet. Selain itu saya juga kadang menggunakan media masa untuk mengupdate berita terkini dan mengaitkan dengan pelajaran yang saya sampaikan agar siswa mengetahui realita dan fakta yang terjadi dan mengaitkan dengan materi yang dipelajari. ${ }^{15}$

Sumber belajar adalah segala sesuatu yang diperlukan dalam proses pembelajaran dapat berupa teks, media cetak, media pembelajaran elektronik, internet, lingkungan, dan sebagainya.

Media pada dasarnya merupakan alat bantu pembelajaran digunakan dalam rangka untuk mengefektifkan komunikasi dan interaksi antar guru dan siswa dalam proses pembelajaran di sekolah, seperti yang dilakukan Ibu Idatul Magfiroh, S.Pd dalam proses pembelajaran kali ini beliau menggunakan laptop dan LCD projector dalam penyampaian materi pendidikan agama islam.

Hal serupa juga disampaikan Ibu Idatul Magfiroh, S.Pd sebagai guru bidang studi PAI:

Saya sudah bisa menggunakan media laptop dalam pembelajaran meski masih sedikit kesulitan jika ada hal yang masih belum saya mengerti, tapi saya selalu belajar menggunakan laptop dan infokus dalam melaksanakan pembelajaran agar memudahkan siswa dalam belajar dan memanfaatkan fasilitas yang ada di sekolah ini. Sebelum saya masuk kelas, siswa sudah menyiapkan media yang akan saya gunakan dalam pembelajaran agar tidak menyita banyak waktu belajar. ${ }^{16}$

\footnotetext{
${ }^{15}$ Wawancara dengan Ibu Idatul Magfiroh, S.Pd. Guru Pendidikan Agama Islam Tanggal 20 Agustus 2018, di Ruang Guru Sekolah Dasar Negeri Bulupitu.

${ }^{16}$ Wawancara dengan Ibu Idatul Magfiroh, S.Pd. Guru Pendidikan Agama Islam Tanggal 20 Agustus 2018, di Ruang Guru Sekolah Dasar Negeri Bulupitu.
} 
Diperkuat dari hasil wawancara dengan Ibu Dra. Ari Khusnul Qibtiyah sebagai Kepala SD Negeri Bulupitu:

Media pembelajaran di Madrasah ini bisa dibilang lengkap dan sudah cukup memadai, bisa memenuhi kebutuhan proses belajar mengajar guru dan siswa dengan baik. Pemilihan materi ajar yang sesuai dengan media yang digunakan dapat menciptakan pembelajaran yang efektif, menyenangkan, serta kondusif. Guru dituntut kreatif dan inovatif dalam mendesain pembelajaran agar menarik dan tidak monoton. Siswa di tuntut aktif agar terciptanya suasana yang interaktif antar guru dan siswa. ${ }^{17}$

Media pembelajaran sangat mempengaruhi proses belajar mengajar, karena media pembelajaran sangat membantu bagaimana siklus perjalanan informasi dari guru maupun dari siswa. Tepatnya pemilihan media pembelajaran akan melahirkan pembelajaran yang kondusif, dan menyenangkan, maka dengan hal demikian tujuan dari materi yang bersangkutan mudah dipahami oleh peserta didik.

Selain metode dan strategi pembelajaran, sumber belajar dan media pembelajaran yang disebutkan di atas, pada kegiatan inti ini juga implementasi pendekatan saintifik pada mata pelajaran pendidikan agama islam diterapkan, langkah kegiatan inti yang pertama dilakukan Ibu Idatul Magfiroh, S.Pd yaitu mengamati, diimplementasikan Ibu Idatul Magfiroh, S.Pd dengan memanfaatkan teknologi informasi yang sesuai dengan prinsip pembelajaran kurikulum 2013.

Ibu Idatul Magfiroh, S.Pd menggunakan langkah awal dalam pembelajaran dengan meminta siswa mengamati tayangan gambar, film atau video, buku pegangan siswa maupun sumber belajar yang lain. Proses menanya dilakukan setelah kegiatan mengamati, Ibu Idatul Magfiroh, S.Pd mengimplementasikan kegiatan menanya pada proses pembelajaran setelah kegiatan mengamati, Ibu Idatul Magfiroh, S.Pd meminta siswa menyusun pertanyaan terkait dengan apa yang sudah mereka amati. Langkah ketiga dalam kegiatan inti yaitu mengeksplorasi, untuk kegiatan mengeksplorasi, Ibu Idatul Magfiroh, S.Pd cenderung menggunakan metode discovery learning dimana siswa diminta untuk mencari dan menemukan sendiri materi sesuai tema yang sedang diajarkan, dengan membentuk kelompokkelompok kecil dalam kelas. Selama proses itu, sumber belajar bisa diambil dari banyak tempat. Selama proses mengeksplorasi, terlihat ada proses mengasosiasi materi antar siswa dalam kelompok-kelompok kecil maupun dalam kegiatan mengkomunikasikan berupa presentasi kelompok. Kegiatan inti yang berikutnya berjalan dengan sempurna, dimana Ibu Idatul Magfiroh, S.Pd membentuk siswa dalam kelompok-kelompok kecil. Kelompokkelompok tersebut melakukan kegiatan menemukan materi sesuai tugas yang diberikan kemudian menyamakan persepsi di antara mereka dan mempresentasikan hasilnya.

Selanjutnya yaitu evaluasi hasil belajar atau penilaian. Berikut hasil wawancara dengan Ibu Idatul Magfiroh, S.Pd sebagai guru bidang studi PAI:

Penilaian hasil belajar pada kurikulum 2013 ini Ada dua macam penilaian, diantaranya penilaian (assesment) adalah proses pengumpulan dan pengolahan informasi untuk mengukur pencapaian hasil belajar peserta didik, dan Penilaian autentik menilai kesiapan peserta didik, serta proses dan hasil belajar secara utuh. Penilaian autentik

${ }^{17}$ Wawancara dengan Ibu Dra. Ari Khusnul Qibtiyah. Kepala Sekolah Dasar Negeri Bulupitu pada Tanggal 25 Agustus 2018 di Ruang Kepala Sekolah. 
memiliki relevansi kuat terhadap pendekatan ilmiah (scientific approach) dalam pembelajaran sesuai dengan tuntutan Kurikulum 2013. Karena penilaian semacam ini mampu menggambarkan peningkatan hasil belajar peserta didik, baik dalam rangka mengamati, menanya, mengeksplorasi, mengasosiasi, dan mengkomunikasikan. ${ }^{18}$

Dalam proses penilaian pada kurikulum 2013 ini ada penilaian diri (self assesment) Penilaian diri merupakan teknik penilaian dengan cara meminta peserta didik untuk mengemukakan kelebihan dan kekurangan dirinya dalam konteks pencapaian kompetensi. Instrumen yang digunakan berupa lembar penilaian diri yang sudah disediakan dan dibagikan kepada siswa oleh pihak sekolah.

\section{c. Kegiatan Akhir}

Berdasarkan observasi atau pengamatan pada kegiatan akhir, Ibu Idatul Magfiroh, S.Pd memberitahukan materi yang akan dibahas pada pertemuan selanjutnya, selain itu Ibu Idatul Magfiroh, S.Pd memberikan tugas sebagai konfirmasi materi yang telah dipelajari dan mengulas kembali sedikit materi yang telah dipelajari agar siswa semakin memahami apa yang telah dia pelajari.

\section{Faktor Pendukung dan Penghambat Guru PAI dalam Mengelola Proses Pembelajaran}

\section{a. Faktor Pendukung}

Berdasarkan hasil observasi dan wawancara di Sekolah Dasar Negeri Bulupitu dapat diketahui bahwa sarana pembelajaran di sekolah ini sudah cukup memadai dan mendukung terhadap proses pembelajaran, penggunaan metode pembelajaran yang didukung dengan media pembelajaran, dan sumber belajar yang cukup memadai di sekolah ini sangat membantu dan mempermudah guru dalam menyampaikan materi pembelajaran.

Berikut hasil wawancara dengan Ibu Idatul Magfiroh, S.Pd:

"Faktor pendukung di sekolah ini sudah memadai dari mulai sarana dan perasarana, gedung sekolah, jadi hanya tinggal mengoptimalkan kerjasama dengan guru, masyarakat sekolah dan stakeholder yang ada agar semuanya berjalan sesuai dengan yang diharapkan". ${ }^{19}$

Dapat disimpulkan bahwa sekolah ini memiliki beberapa faktor pendukung dalam proses pengelolaan pembelajaran diantaranya: sekolah memiliki tenaga SDM (sumber daya manusia) profesional dari segi guru, memiliki cukup siswa yang aktif yang memiliki rasa ingin tahu yang tinggi terhadap perkembangan ilmu pengetahuan, dari segi sarana dan prasarana sudah memadai dan mendukung.

\section{b. Faktor Penghambat}

Kompetensi guru dalam mengelola proses pembelajaran tentunya menjadi perhatian utama dalam pelaksanaan pembelajaran di kelas, dalam pelaksanaannya tidak lepas dari kendala atau hambatan.

\footnotetext{
${ }^{18}$ Wawancara dengan Ibu Idatul Magfiroh, S.Pd. Guru Pendidikan Agama Islam Tanggal 20 Agustus 2018, di Ruang Guru Sekolah Dasar Negeri Bulupitu.

${ }^{19}$ Wawancara dengan Ibu Idatul Magfiroh, S.Pd. Guru Pendidikan Agama Islam Tanggal 20 Agustus 2018, di Ruang Guru Sekolah Dasar Negeri Bulupitu.
} 
Hal yang menjadi kesulitan dalam mengelola proses pembelajaran ini adalah dalam hal penilaian sikap. Guru pendidikan agama islam merasa kesulitan dalam melaksanakan penilaian ini dikarenakan guru harus mendeskripsikan sikap setiap siswa dalam penilaian ini. Guru mengaku kesulitan karena siswa yang diajar olehnya tidak sedikit melainkan banyak, jadi hal seperti itu yang membuat guru berat dalam memberikan penilaian.

Hambatan selanjutnya yaitu masih ada sebagian siswa kurang siap untuk mandiri dalam belajar, misalnya saja dalam proses pembelajaran pada kegiatan menanya hanya ada beberapa siswa yang aktif bertanya dan sebagian siswa lainnya hanya memperhatikan dan mendengarkan tanpa mengajukan pertanyaan, hal ini karena siswa masih terbiasa dengan sistem konvensional yaitu siswa pasif dalam pembelajaran dan hanya guru yang aktif mengajar dengan metode ceramah saja.

\section{Upaya Guru PAI Mengatasi Hambatan dalam Mengelola Proses Pembelajaran}

Segala upaya yang dilakukan oleh guru PAI di Sekolah Dasar Negeri Bulupitu demi tercapainya tujuan pembelajaran diantaranya:

Kepala sekolah selalu menugaskan guru PAI untuk mengikuti Pelatihan, Workshop, maupun Diklat Kurikulum 2013, hal ini dimaksudkan agar guru lebih memahami bagaimana melaksanakan penilaian sikap terhadap siswa demi tercapainya tujuan pembelajaran yang optimal.

Guru selalu berupaya mengembangkan kompetensi pedagogiknya, mengarahkan siswa untuk lebih aktif dalam kelas melakukan pendekatan dan memotivasi siswa untuk dapat mengikuti proses pembelajaran sesuai dengan yang diharapkan oleh guru.

\section{PEMBAHASAN}

Guru pendidikan agama islam menjelaskan kompetensi pedagogik guru meliputi:

"Kemampuan dalam memahami peserta didik, kemampuan merancang pembelajaran, kemampuan melaksanakan proses pembelajaran, kemampuan menilai proses dan hasil, dan kemampuan mengembangkan potensi peserta didik". ${ }^{20}$

Sebelum memasuki ruang kelas guru mempersiapkan bahan ajar (buku pegangan guru), media pembelajaran (laptop dan LCD projector), beserta RPP (Rancangan Pelaksaan Pembelajaran) yang harus disusun sebelumnya. Hasil tersebut dapat dijabarkan sebagai berikut:

\section{Kegiatan Awal}

Sebelum memulai pelajaran pendidikan agama islam, Ibu Idatul Magfiroh, S.Pd melakukan absensi terlebih dahulu dan mengkondisikan siswa, sebelum memulai pelajaran siswa ditanya tentang kabar dan kondisi kesehatan mereka dan tidak lupa pula beliau memotivasi siswa dengan cara memberikan perhatian yang lebih kepada siswa yang kurang bersemangat di dalam kelas, kemudian baru memulai proses belajar mengajar dengan mengkonfirmasi materi sebelumnya, Ibu Idatul Magfiroh, S.Pd melakukan tes dengan mengajukan pertanyaan secara lisan kepada siswa, dan siswa yang bisa menjawab selalu diberi reward sebuah permen, walaupun tidak seberapa tapi siswa sangat antusias untuk menjawab 
soal-soal Hal ini dilakukan untuk mengukur sejauh mana pemahaman siswa terhadap materi sebelumnya.

Kegiatan awal pembukaan proses belajar mengajar terlebih dahulu guru mengkondisikan siswa, melakukan apersepsi, konfirmasi terhadap materi-materi yang dibahas pada pertemuan sebelumnya. Serta melakukan tes/kuis yang bisa meningkatkan kemampuan siswa terhadap materi sebelumnya dan materi yang akan dibahas.

\section{Kegiatan Inti Pembelajaran}

Pertama yang menjadi pertimbangan yaitu, pemilihan metode pembelajaran disesuaikan dengan kompetensi atau materi yang harus dikuasai siswa dalam waktu yang tersedia. Pemilihan dan penggunaan strategi atau metode pembelajaran di SD Negeri Bulupitu sudah mengarah pada pemilihan strategi atau metode pembelajaran yang dianjurkan dalam Kurikulum 2013, dapat disimpulkan bahwa metode dan strategi pembelajaran yang digunakan.

Terciptanya proses belajar mengajar yang menyenangkan yaitu ketika Ibu Idatul Magfiroh, S.Pd memberikan kebebasan kepada siswa untuk melakukan sendiri dibawah bimbingan guru, siswa lebih mudah mengingat dan paham materi ketika mereka terlibat langsung dalam proses tersebut.

Dalam proses belajar mengajar menggunakan berbagai sumber belajar, antara lain: buku, LKS, buku-buku penunjang lainnya, internet, media masa, dan lain sebagainya.

Media pada dasarnya merupakan alat bantu pembelajaran digunakan dalam rangka untuk mengefektifkan komunikasi dan interaksi antar guru dan siswa dalam proses pembelajaran di sekolah, seperti yang dilakukan Ibu Idatul Magfiroh, S.Pd dalam proses pembelajaran kali ini beliau menggunakan laptop dan LCD projector dalam penyampaian materi pendidikan agama islam.

Media pembelajaran sangat mempengaruhi proses belajar mengajar, karena media pembelajaran sangat membantu bagaimana siklus perjalanan informasi dari guru maupun dari siswa. Tepatnya pemilihan media pembelajaran akan melahirkan pembelajaran yang kondusif, dan menyenangkan, maka dengan hal demikian tujuan dari materi yang bersangkutan mudah dipahami oleh peserta didik.

Selain metode dan strategi pembelajaran, sumber belajar dan media pembelajaran yang disebutkan di atas, pada kegiatan inti ini juga implementasi pendekatan saintifik pada mata pelajaran pendidikan agama islam diterapkan, langkah kegiatan inti yang pertama dilakukan Ibu Idatul Magfiroh, S.Pd yaitu mengamati, diimplementasikan Ibu Idatul Magfiroh, S.Pd dengan memanfaatkan teknologi informasi yang sesuai dengan prinsip pembelajaran kurikulum 2013.

Langkah ketiga dalam kegiatan inti yaitu mengeksplorasi, untuk kegiatan mengeksplorasi, Ibu Idatul Magfiroh, S.Pd cenderung menggunakan metode discovery learning dimana siswa diminta untuk mencari dan menemukan sendiri materi sesuai tema yang sedang diajarkan, dengan membentuk kelompok-kelompok kecil dalam kelas. Selama proses itu, sumber belajar bisa diambil dari banyak tempat. Selama proses mengeksplorasi, terlihat ada proses mengasosiasi materi antar siswa dalam kelompok-kelompok kecil maupun dalam kegiatan mengkomunikasikan berupa presentasi kelompok. Kegiatan inti yang berikutnya berjalan dengan sempurna, dimana Ibu Idatul Magfiroh, S.Pd membentuk siswa dalam kelompok-kelompok kecil. Kelompok-kelompok tersebut melakukan kegiatan menemukan 
materi sesuai tugas yang diberikan kemudian menyamakan persepsi di antara mereka dan mempresentasikan hasilnya.

Selanjutnya yaitu evaluasi hasil belajar atau penilaian. Berikut hasil wawancara dengan Ibu Idatul Magfiroh, S.Pd

Dalam proses penilaian pada kurikulum 2013 ini ada penilaian diri (self assesment) Penilaian diri merupakan teknik penilaian dengan cara meminta peserta didik untuk mengemukakan kelebihan dan kekurangan dirinya dalam konteks pencapaian kompetensi. Instrumen yang digunakan berupa lembar penilaian diri yang sudah disediakan dan dibagikan kepada siswa oleh pihak sekolah.

\section{Kegiatan Akhir}

Guru memberitahukan materi yang akan dibahas pada pertemuan selanjutnya, selain itu memberikan tugas sebagai konfirmasi materi yang telah dipelajari dan mengulas kembali sedikit materi yang telah dipelajari agar siswa semakin memahami apa yang telah dia pelajari.

\section{Faktor Pendukung dan Penghambat Guru PAI dalam Mengelola Proses Pembelajaran}

\section{a. Faktor Pendukung}

Faktor pendukung terlaksananya proses pembelajaran yang efektif di Sekolah Dasar Negeri Bulupitu diantaranya adalah:

1) Sarana pembelajaran di Sekolah ini sudah cukup memadai dan mendukung dari segi gedung yang sudah dimiliki, buku pegangan guru dan buku siswa yang cukup terpenuhi begitu pula dengan media pembelajaran.

2) Jumlah SDM (sumber daya manusia) atau tenaga guru sebagian besar mengajar sesuai dengan keahlian dan kompetensi yang dimiliki, partisipasi masyarakat sekolah dan stakeholder yang mendukung terhadap perkembangan dan kemajuan sekolah. Selain tenaga SDM (sumber daya manusia) profesional dari segi guru, Sekolah Dasar Negeri Bulupitu ini cukup memiliki siswa yang aktif dan memiliki rasa ingin tahu yang tinggi terhadap perkembangan ilmu pengetahuan.

\section{b. Faktor Penghambat}

Proses pembelajaran yang efektif. tentunya menjadi perhatian utama dalam pelaksanaan pembelajaran di kelas, dalam pelaksanaannya tidak lepas dari kendala atau hambatan. Berikut ini adalah hambatan yang peneliti temui di Sekolah Dasar Negeri Bulupitu dalam mengelola proses pembelajaran :

1) Pelaksanaan penilaian sikap. Guru merasa kesulitan dalam melaksanakan penilaian ini dikarenakan guru harus mendeskripsikan sikap setiap siswa dalam penilaian ini. Guru mengaku kesulitan karena siswa yang diajar olehnya tidak sedikit melainkan banyak, jadi hal seperti itu yang membuat guru berat dalam memberikan penilaian.

2) Masih ada siswa yang kurang siap untuk mandiri dalam belajar, hal ini karena siswa masih terbiasa dengan sistem konvensional yaitu siswa pasif dalam pembelajaran dan hanya guru yang aktif mengajar dengan metode ceramah saja. 


\section{Upaya Guru PAI Mengatasi Hambatan dalam Mengelola Proses Pembelajaran}

Upaya yang dilakukan oleh guru PAI di Sekolah Dasar Negeri Bulupitu demi tercapainya tujuan pembelajaran diantaranya:

1) Guru PAI berupaya mengikuti Pelatihan, Workshop, maupun Diklat Kurikulum 2013 menambah pengetahuan baru melalui seminar/diskusi, menambah pengetahuan baru melalui buku-buku. hal ini dimaksudkan agar guru lebih memahami bagaimana melaksanakan penilaian sikap terhadap siswa. Sehingga akan terciptanya guru PAI yang berwawasan tinggi dan professional sesuai dengan kompetensi yang dimilikinya terutama dalam mengelola proses pembelajaran.

2) Dalam proses pembelajaran yang berlangsung, guru berupaya memberikan reward bagi siswa yang aktif bertanya, hal ini bertujuan agar siswa lebih aktif dan percaya diri dalam mengungkapkan ide-idenya.

3) Selain itu sekolah terus membenahi dan melengkapi sarana dan prasarana, meskipun pada dasarnya sarana prasarana di Sekolah Dasar Negeri Bulupitu sudah cukup memadai. Upaya tersebut dimaksudkan untuk mengoptimalkan pembelajaran dan memudahkan guru dalam penyampaian materi.

\section{Kesimpulan}

\section{KESIMPULAN DAN SARAN}

Berdasarkan data dari hasil penelitian yang diperoleh melalui wawancara, observasi, dan studi dokumentasi maka dapat disimpulkan bahwa kompetensi pedagogik guru PAI dalam mengelola proses pembelajaran di Sekolah Dasar Bulupitu sudah terlaksana dengan baik. Kompetensi pedagogic guru dalam mengelola proses pembelajaran tersebut terwujud dalam lima kegiatan sebagai berikut:

1. Kemampuan dalam memahami peserta didik melalui pendekatan-pendekatan, Guru melakukan pendekatan terhadap siswa yang kurang bergairah dalam proses belajar mengajar, memberikan perhatian dan dorongan motivasi.

2. Kemampuan dalam membuat perancangan pembelajaran, guru PAI sudah menyusun dan mengembangkan penyusunan Rencana Pelaksanaan Pembelajaran (RPP).

3. Kemampuan dalam melaksanakan pembelajaran, guru PAI berusaha melaksanakan proses pembelajaran dengan baik, serta tidak membatasi sumber belajar bagi siswa.

4. Kemampuan dalam mengevaluasi hasil belajar, guru telah melaksanakan penilaian untuk mengukur pencapaian hasil belajar peserta didik, dan menggunakan penilaian autentik yaitu menilai kesiapan peserta didik, serta proses dan hasil belajar secara utuh meskipun kurang maksimal.

5. Kemampuan dalam megembangkan potensi peserta didik yang yang dapat terlihat melalui proses pembelajaran, guru PAI memberikan arahan kepada peserta didik untuk mengembangkan potensinya dengan mengikuti kompetisi-kompetisi yang ada, baik yang diadakan oleh sekolah sendiri, maupun di luar sekolah.

Hambatan yang dialami guru dalam mengelola proses pembelajaran diantaranya yaitu: Pelaksanaan penilaian sikap. Guru merasa kesulitan dalam melaksanakan penilaian ini dikarenakan guru harus mendeskripsikan sikap setiap siswa dalam penilaian ini. Hambatan lainnya yaitu, masih ada siswa yang kurang siap untuk mandiri dalam belajar. 
Disamping itu, guru PAI berupaya dalam mengatasi hambatan dengan mengikuti Pelatihan, Workshop, dan seminar/diskusi, menambah pengetahuan baru melalui bukubuku.hal ini dimaksudkan agar guru lebih memahami bagaimana melaksanakan penilaian sikap terhadap siswa. Dan guru selalu memotivasi siswa dan memberikan reward kepada peserta didik yang aktif dalam proses pembelajaran.

\section{Saran}

Dengan memperhatikan kesimpulan diatas, saran dalam penelitian ini adalah:

1. Kepala sekolah harus mengadakan pelatihan-pelatihan, sosialisasi secara berkala kepada guru tentang pelaksanaan kurikulum 2013, dalam memaksimalkan proses pembelajaran terutama kepada guru PAI.

2. Guru hendaknya selalu meningkatkan pemahaman mengenai kurikulum 2013 dengan mengikuti seminar, workshop, atau mempelajari buku-buku tentang implementasi kurikulum 2013. Aktif dalam kelompok kerja guru (KKG) dan musyawarah guru mata pelajaran (MGMP), untuk meningkatkan kompetensi guru dalam upaya meningkatkan kualitas pendidikan.

\section{DAFTAR PUSTAKA}

Aqib, Zainal. (2011). Pendidikan Karakter Membangun Perilaku Positif anak bangsa.

Bandung: Yrama Widya.

Arikunto, Suharsimi. (2005). Manajemen Penelitian. Jakarta: PT Rineka Cipta.

Aziz, Hamka Abdul. (2012). Karakter Guru Profesional. Jakarta: Al-mawardi Prima.

Daryanto. (2013). Standard Kompetensi dan Penilaian Kinerja Guru Profesional. Yogyakarta: Gava Media.

Direktorat Jenderal Pendidikan Dasar dan Menengah. (2016). Panduan Teknis Pembelajaran dan Penilaian. Jakarta: Kementrian Pendidikan dan Kebudayaan.

Direktorat Jenderal Pendidikan Dasar dan Menengah. (2016). Materi Umum dan Materi Pokok. Jakarta: Kementrian Pendidikan dan Kebudayaan RI.

Hosnan. (2016). Pendekatan Saintifik dan Kontektual dalam Pembelajaran Abad 21. Bogor: Ghalia Indonesia.

Irwantoro, Nur. Yusuf Suryana. (2015). Kompetensi Pedagogik. Surabaya: Genta Group Production.

Kurniadin, Didin. (2012). Manajemen Pendidikan Jogjakarta: Ar-ruzz Media.

Kuniasih, imas. Berlin Sani. (2017). Kupas Tuntas Kompetensi Pedagogik Teori dan Praktik. Kata Pena.

Moleong, Lexy J. (2012). Metode Penelitian Kualitatif. Bandung: PT. Remaja Rosdakarya Sugiyono. (2015). Metode Penelitian Kuantitaif, Kualitatif dan $R \& D$. Bandung: Alfabeta. Sugiyono. (2017). Metode Penelitian Kuantitaif, Kualitatif dan $R \&$ D . Bandung: Alfabeta. Sukandarrumidi. (2006). Metodologi Penelitian. Yogyakarta: Gadjah Mada Unversity Press.

Sumadinata, Nana Sayodih. (2012). Metode Penelitian Pendidikan. Bandung: PT. Rmaja Rosdakarya.

Suparlan. (2003). Menjadi Guru Efektif. Yogyakarta: Hikayat.

Suryabrata, Sumardi. (2005). Metodologi Penelitian. Jakarta: PT Raja Grafindo Persada. 
Jurnal Tinta, Vol. 1 No. 2, September 2019, Hal. 93-105

Taufiqi. (2014). 49 Hari Menjadi Guru Idola Luar Biasa dan Kaya Raya. Malang: Dream Litera.

Wahyudi, Imam. 2012. Pengembangan pendidikan. Jakarta: Prestasi Pustaka.

Yasin, Ahmad Fatah. Pengembangan Kompetensi Pedagogik Guru Pendidikan Agama Islam di Madrasah (Studi Kasus di MIN Malang I). Jurnal El- Qudwah. April 2012. Vol.1, No.5, pp. 157-181. http://ejournal.uin-malang.ac.id/index.php/lemlit/article/view/ 1942 (diakses pada 9 September 2018).

Zulaeha, Dewi Laila. Kompetensi Pedagogik Guru Akidah Akhlak Dalam Penggunaan Media Pembelajarannya (Study Kasus di MTs Negeri Pangandaran). http://digilib.uinsuka.ac.id/10184/ diakses pada 1 Juni 2018. 